GROUND GRAVITY GEOPHYSICAL SURVEY OF THE HOLITNA BASIN AREA, ALASKA, DATA COMPILATION

David L. LePain, Abraham M. Emond, and Edcon, Inc.

Raw Data File 2020-8

2020

STATE OF ALASKA

DEPARTMENT OF NATURAL RESOURCES

DIVISION OF GEOLOGICAL \& GEOPHYSICAL SURVEYS
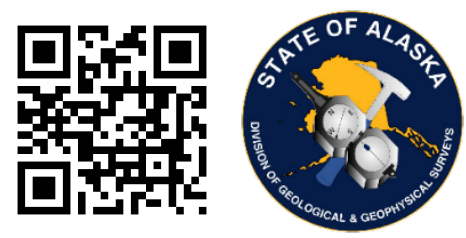


\section{STATE OF ALASKA}

Mike Dunleavy, Governor

\section{DEPARTMENT OF NATURAL RESOURCES}

Corri A. Feige, Commissioner

\section{DIVISION OF GEOLOGICAL \& GEOPHYSICAL SURVEYS}

Steve Masterman, State Geologist \& Director

Publications produced by the Division of Geological \& Geophysical Surveys are available to download from the DGGS website (dggs.alaska.gov). Publications on hard-copy or digital media can be examined or purchased in the Fairbanks office:

\section{Alaska Division of Geological \& Geophysical Surveys (DGGS)}

3354 College Road | Fairbanks, Alaska 99709-3707

Phone: 907.451.5010 | Fax 907.451.5050

dggspubs@alaska.gov $\mid$ dggs.alaska.gov

DGGS publications are also available at:

Alaska State Library, Historical

Collections \& Talking BookCenter

395 Whittier Street

Juneau, Alaska 99801

Alaska Resource Library and

Information Services (ARLIS)

3150 C Street, Suite 100

Anchorage, Alaska 99503

\section{Suggested citation:}

LePain, D.L., Emond, A.M., and Edcon, Inc., 2020, Ground gravity geophysical survey of the

Holitna basin area, Alaska: Alaska Division of Geological \& Geophysical Surveys

Raw Data File 2020-8, 5p. http://doi.org/10.14509/30461
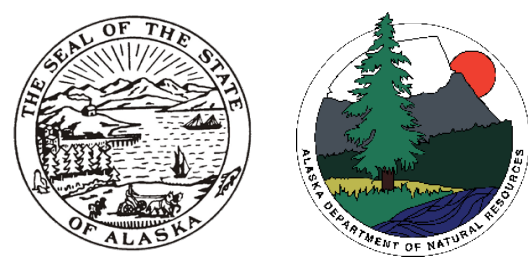


\title{
GROUND GRAVITY GEOPHYSICAL SURVEY OF THE HOLITNA BASIN AREA,
} ALASKA, DATA COMPILATION

\author{
David L. LePain', Emond, A.M. ${ }^{1}$, Edcon, Inc.
}

\begin{abstract}
Gravity data were acquired at 1,175 stations during the period April 13 to May 3, 1982 by EDCON, Inc. using a helicopter-borne inertial surveying system and LaCoste and Romberg G-meters. Of the total number of stations, 1,156 were acquired along one of 19 lines and the remaining 19 stations were control points or gravity bases. The survey is located in southwestern Alaska approximately 325 kilometers west of Anchorage, Alaska. Stations acquired along the 19 lines. In general, gravity stations were spaced approximately 1,600 meters apart along northwest-southeast oriented lines which were spaced 9,500 meters apart.
\end{abstract}

\section{PURPOSE}

These data were collected to assist the state in assessing the hydrocarbon potential of the Holitna Basin area. The gravity data were intended to be interpreted and integrated with available geoscience data.

\section{SURVEY OVERVIEW DESCRIPTION}

This document provides an overview of the survey and includes text and figures of select primary and derivative products of this survey. A table of digital data packages available for download is provided to assist users in data selection. For reference, a catalog of the available maps is presented in reduced resolution. Please consult the metadata, project report, and digital data packages for more information and data.

\section{ACKNOWLEDGMENTS}

Funding was provided by the Alaska State Legislature.

\section{REFERENCES}

Edcon, Inc., 2001, Edcon land gravity survey, Holitna basin, southwest Alaska: Alaska Division of Geological \& Geophysical Surveys Geophysical Report 2001-1, 1 DVD. http://doi.org/10.14509/2725

\footnotetext{
${ }^{1}$ Alaska Division of Geological \& Geophysical Surveys, 3354 College Road, Fairbanks, Alaska 99709-3707
} 


\begin{tabular}{ccl}
$\begin{array}{c}\text { AVAILABLE DATA } \\
\text { Data Type }\end{array}$ & Provider & \multicolumn{1}{c}{ Description } \\
\hline ascii_data & contractor & ASCll format line data, other ASCIl data \\
\hline documents & contractor & Project and interpretation reports \\
\hline grids_geosoft & DGGS & $\begin{array}{l}\text { Geosoft-format grids, these grids can be viewed in } \\
\text { ESRI ArcMap using a free plugin from Geosoft or the } \\
\text { free viewer available from Geosoft }\end{array}$ \\
\hline images_registered & DGGS & GeoTiff format images of all gridded data \\
\hline maps_pdf_format & contractor & Printable maps in pdf format \\
\hline vector_data & contractor and DGGS & survey boundary in ESRI shapefile (SHP) format \\
\hline
\end{tabular}




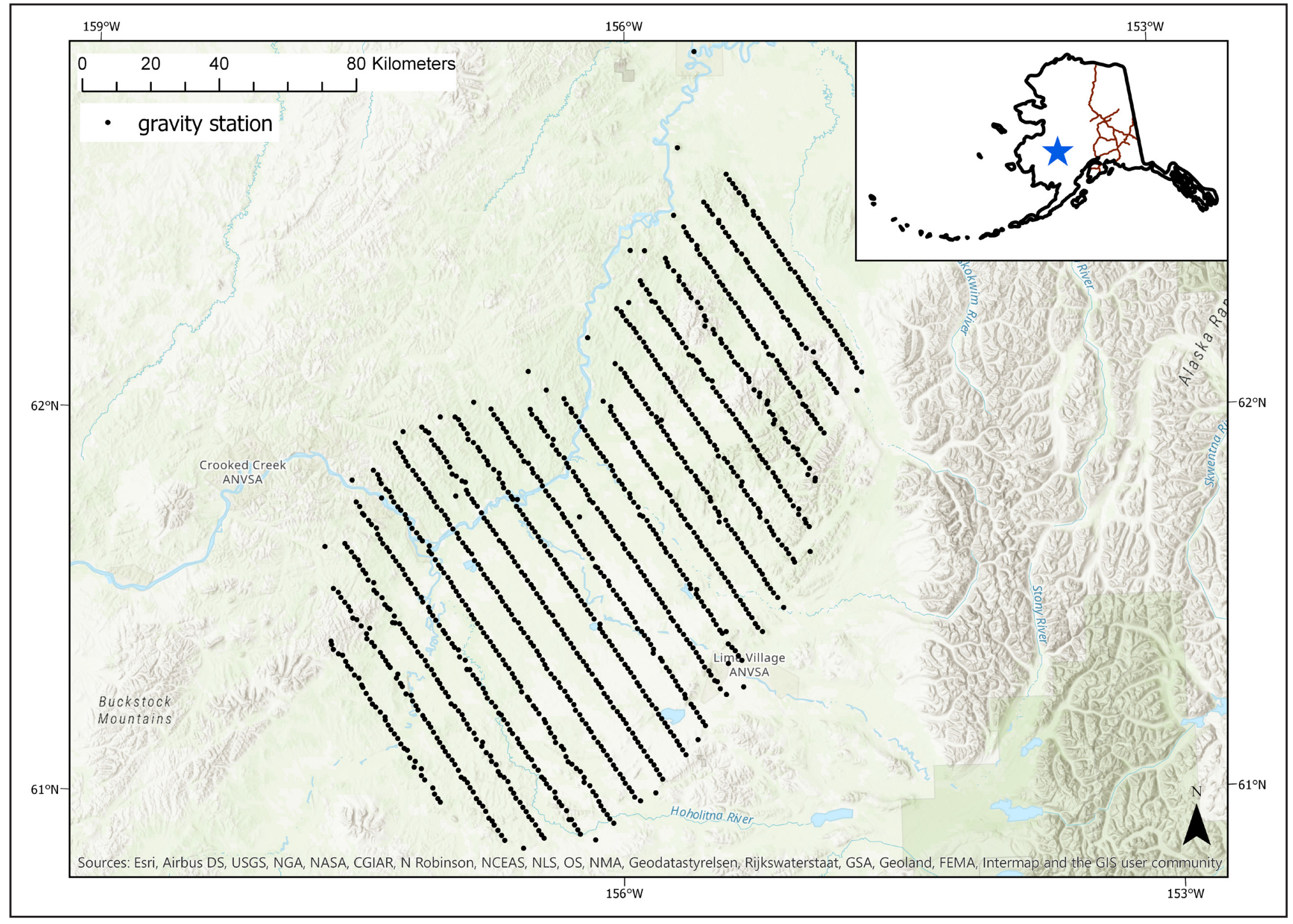

Figure 1. Holitna gravity station map with topographic basemap. 


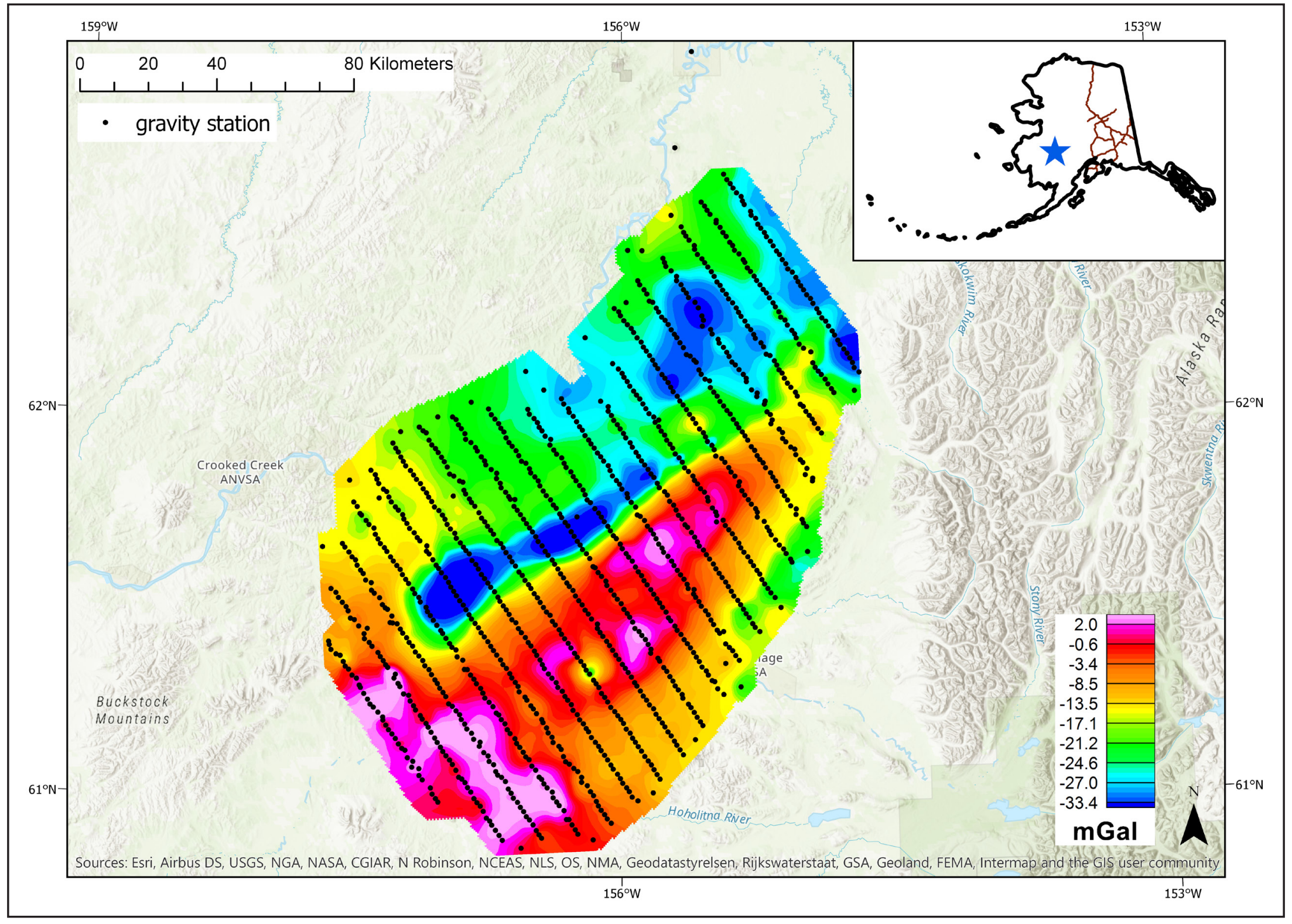

Figure 2. Holitna gravity complete Bouguer Anomaly grid with topographic basemap. 
Table 1. Copies of the following maps are included at the end of this booklet. The low-resolution, page-size maps included in this booklet are intended to be used as a search tool and are not the final product. Large-scale, full-resolution versions of each map are available to download on this publication's citation page: http://doi.org/10.14509/30461

\begin{tabular}{|l|l|}
\hline \multicolumn{1}{|c|}{ Map Title } & \multicolumn{1}{|c|}{ Description } \\
\hline holitnagrav_dembw.pdf & color map of $2.67 \mathrm{~g} / \mathrm{cc}$ Complete Bouguer gravity contoured at $1 \mathrm{mGal}$ \\
\hline holitnagrav_boug.pdf & black and white map of $2.67 \mathrm{~g} / \mathrm{cc}$ Complete Bouguer gravity contoured at $1 \mathrm{mGal}$ \\
\hline holitnagrav_bougbw.pdf & color map of terrain contoured at 40 meters with station locations annotated \\
\hline holitnagrav_dem.pdf & black and white map of terrain contoured at 40 meters with station locations annotated \\
\hline
\end{tabular}









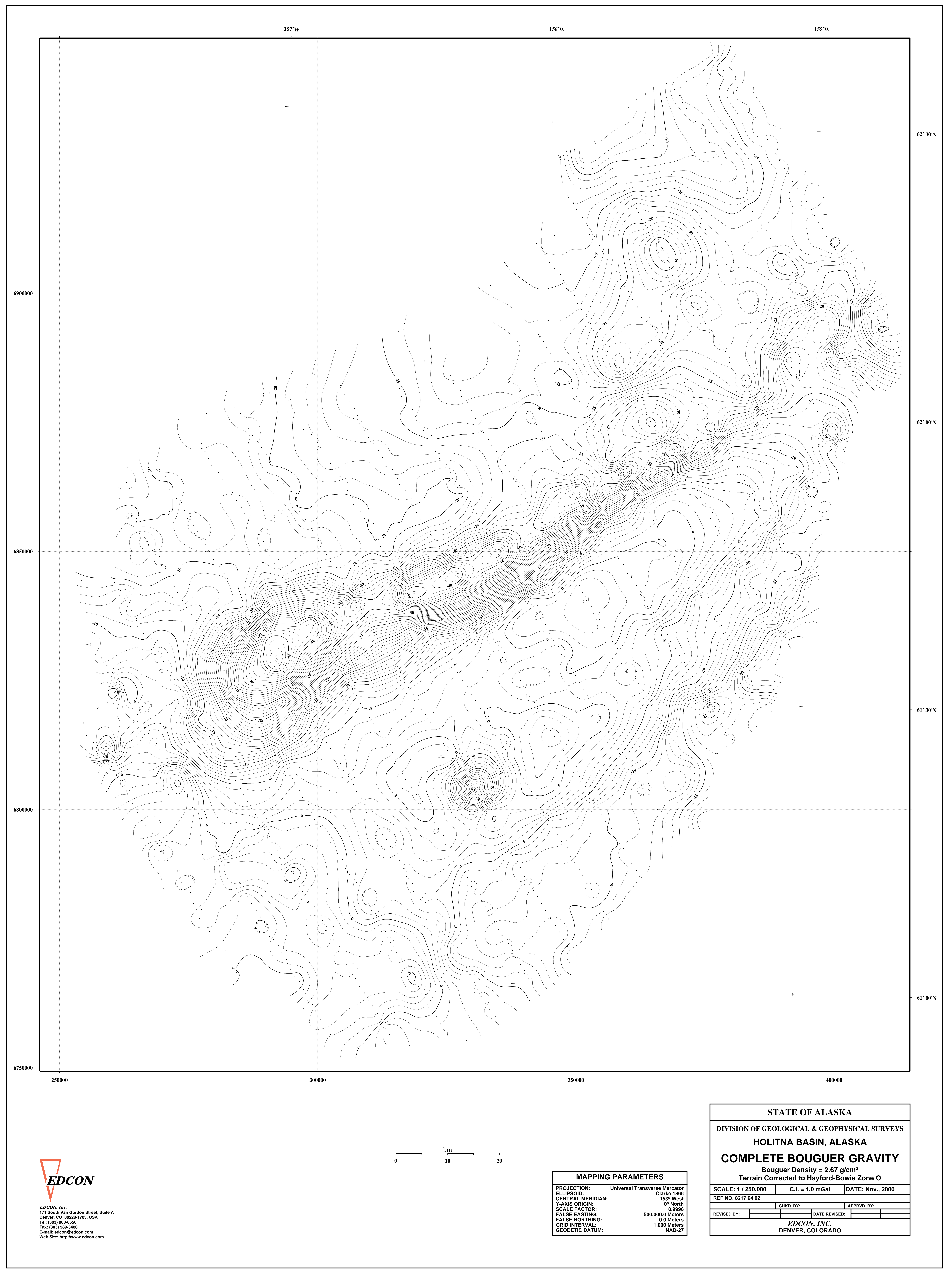




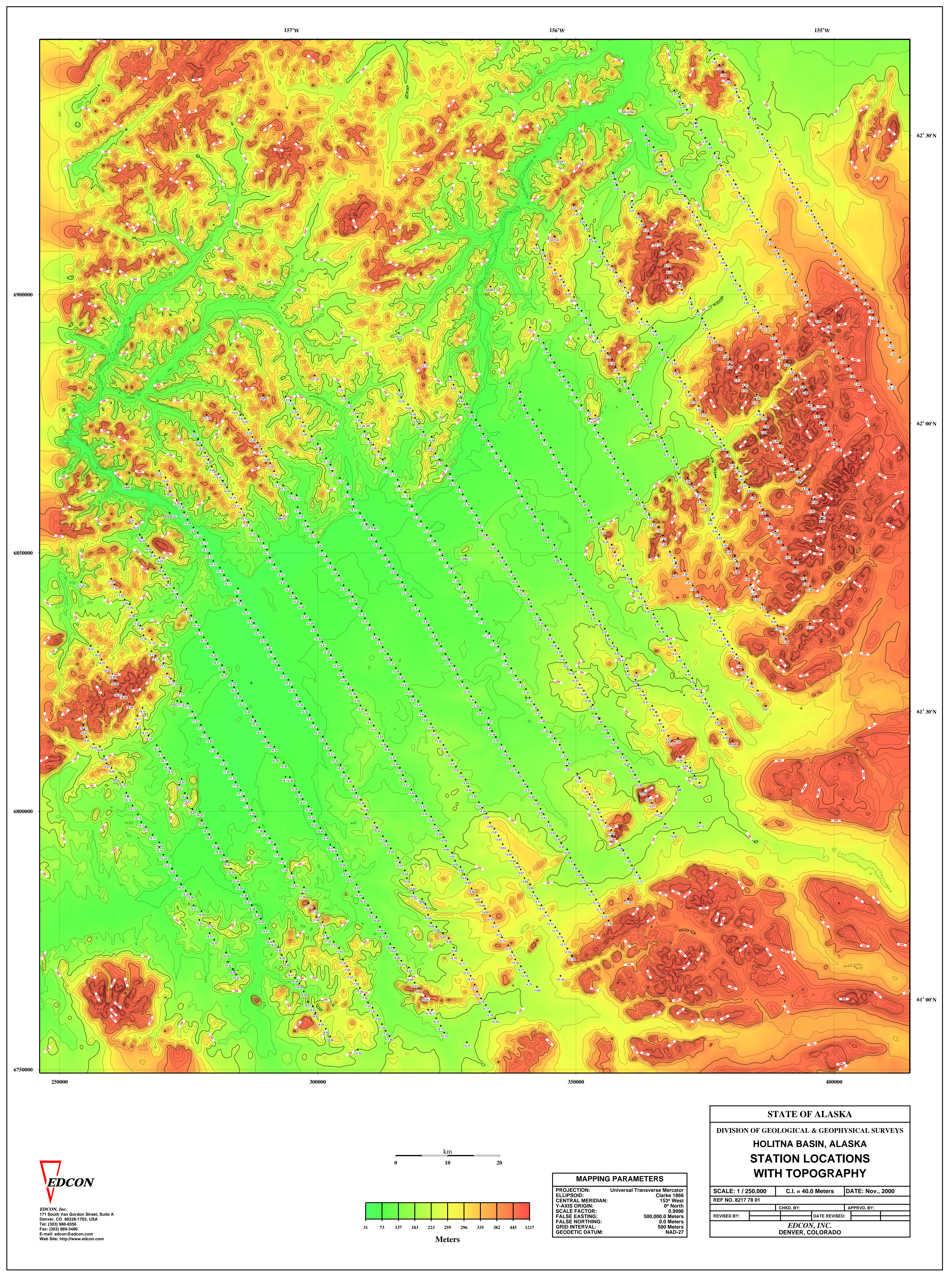




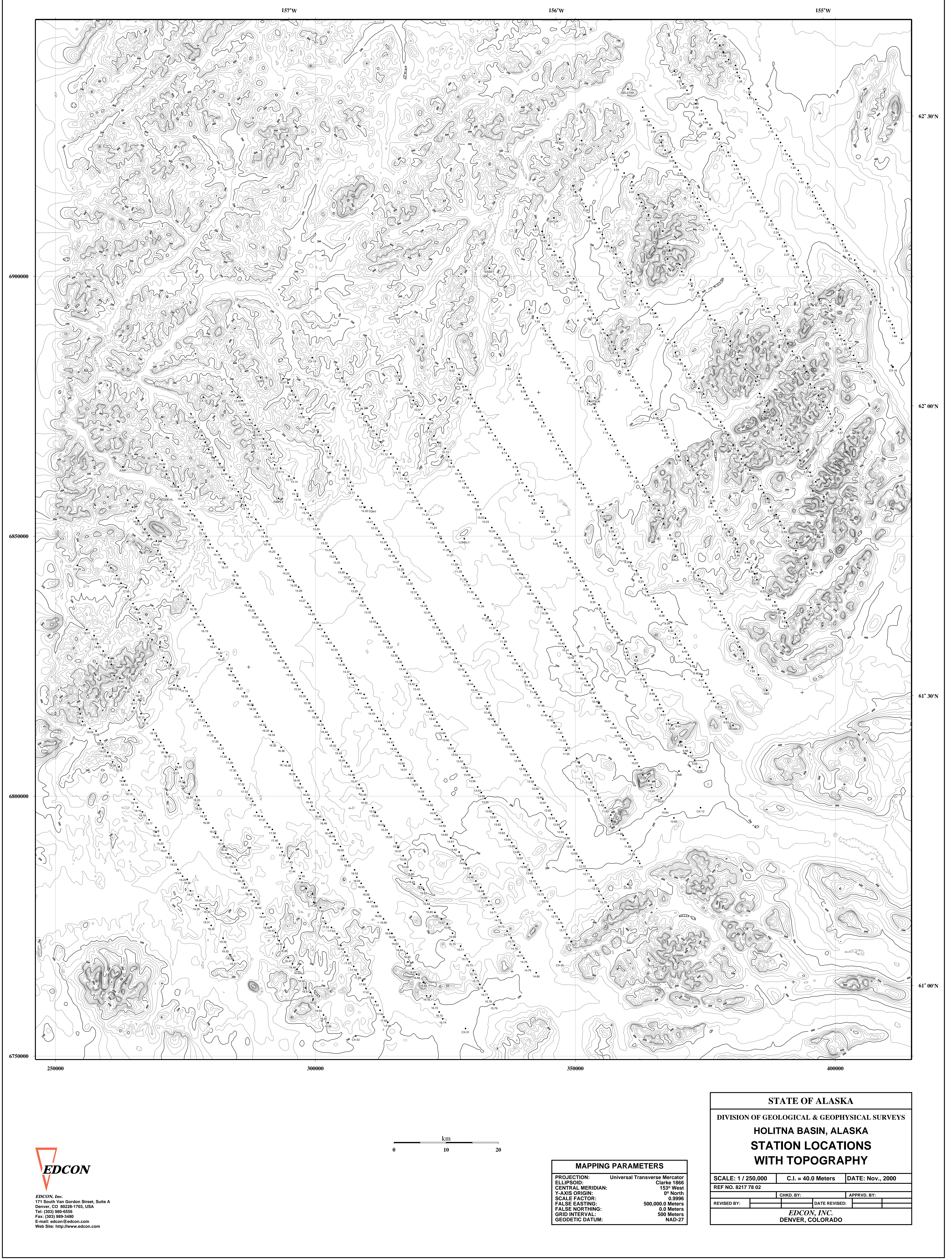

